\title{
EDUKASI RUMAH TANGGA BEBAS ASAP ROKOK
}

\section{EDUCATION OF HOUSEHOLD FREE SMOKING CIGARETTE}

\author{
Septian Emma Dwi Jatmika ${ }^{\# 1}$ \\ \#1 Ilmu Kesehatan Masyarakat, Universitas Ahmad Dahlan, \\ Jl. Prof. Dr. Soepomo, S.H., Janturan, Warungboto, Umbulharjo, Yogyakarta. \\ ${ }^{1}$ septianemmadikm. uad.ac.id
}

\begin{abstract}
Abstrak
Perokok pasif akan menerima efek asap rokok yang tidak sedikit pada kesehatannya. Berdasarkan hasil survey pendahuluan, terdapat 56,76\% anggota keluarga yang merokok di RT 06 Dusun Ponegaran, Desa Jambidan, Banguntapan, Bantul. Sebagain besar perokok merokok didalam rumah. Hal ini akan berdampak pada anakanak sebagai perokok pasif. Tujuan kegiatan adalah mengedukasi tentang dampak paparan asap rokok orang lain pada perokok pasif, agar mereka dapat terhindar dari paparan asap rokok. Metode pelaksanaan kegiatan ini adalah penyuluhan menggunakan media leaflet yang dilakukan dengan mengujungi rumah warga satu per satu (door to door). Materi kegiatan yang disampaikan meliputi dampak paparan asap rokok orang lain pada perokok pasif, dampak ekonomi akibat konsumsi rokok dan peran keluarga dalam pengendalian perilaku merokok. Masih perlu adanya penyuluhan atau intervensi tentang dampak akibat merokok, dampak paparan asap pada perokok pasif maupun aktif, dan pengendalian terhadap perilaku merokok. Mengingat bahaya rokok terhadap kesehatan bagi masyarakat. Diharapkan agar kader atau tenaga kesehatan dapat memberikan penyuluhan dengan frekuensi yang lebih sering dan ditambahkan materi mengenai rumah bebas asap rokok.
\end{abstract}

Kata Kunci: rumah tangga bebas asap rokok, asap rokok orang lain, AROL, dampak ekonomi, peran keluarga

Abstract

Passive smokers will receive the effects of cigarette smoke that is not small on their health. Based on the results of preliminary survey, there were $\mathbf{5 6 . 7 6 \%}$ of family members who smoked in RT 06, Ponegaran Hamlet, Jambidan Village, Banguntapan, Bantul. Meanwhile, most smokers smoke in the house. This will have an impact on children as passive smokers. The purpose this community service is to educate the effects of s smoke exposure on passive smoker thus avoiding smoke exposure. The implementation method of this activity is counseling using leaflet which is delivered by visiting the houses of the residents one by one (door to door). The activity material presented includes the effects of smoke exposure on other passive smoker, the economic impact of cigarette consumption and the role of families in controlling smoking behavior. There is still a need for counseling or interventions on the effects of smoking, the effects of smoke exposure on passive and active smokers, and control of smoking behavior. Given the dangers of smoking to health for the community. It is hoped that cadres or health workers can provide counseling with a more frequent frequency and add material about smoke-free homes.

Keywords: smoke-free households, other people's cigarette smoke, AROL, economic impact, family role

\section{PENDAHULUAN}

Asap rokok mengandung sekitar 500 partikel gas berbahaya, (tar dan nikotin). Perokok pasif akan menerima efek asap rokok yang tidak sedikit pada kesehatannya. Laporan dari kementrian kesehatan Amerika Serikat menunjukkan bahwa anak-anak dan wanita adalah kelompok dengan risiko terbesar untuk menderita kelainan akibat asap rokok (Rai \& Artana, 2009)

Seorang anak, bayi dan orang tua memiliki waktu tinggal di dalam ruangan lebih banyak (Mukono, 2005) . Di antara berbagai bahan pencemar dalam ruang (indoor), asap rokok merupakan pencemar yang biasanya mempunyai kuantitas paling banyak. Hal ini disebabkan besarnya aktivitas merokok di dalam ruangan yang sering dilakukan oleh mereka yang mempunyai kebiasaan merokok (Pudjiastuti,dkk, 1998). Makin meningkatnya masalah perokok aktif di lingkungan kerja atau tempat tinggal yang tertutup memungkinkan terjadinya pengaruh pada perokok pasif (Bustan, 2000).

Studi lain menunjukan bahwa sesorang penderita asma bronkial yang terkena asap rokok selama satu 
jam, mengalami $20 \%$ kerusakan fungsi paru. Pada anak-anak efek rokok lebih parah, ini disebabkan diameter saluran pernapasan anak-anak yang sempit, sehingga jumlah asap rokok yang masuk kedalam saluran pernapasan menjadi lebih banyak dibandingkan berat badannya, selain itu karena sistem pertahanan tubuh yang belum berkembang. (Emilda, 2014)

Munculnya gejala asma bronkial anak-anak jauh lebih cepat dibanding orang dewasa. Hasil analisis 4.000 orang anak berumur 0-5 tahun menunjukan bahwa anak-anak yang orang tuanya merokok 10 batang sehari, menyebabkan peningkatan jumlah kasus asma bronkial serta mempercepat munculnya gejala asma bronkial pada anak-anak. Begitu juga anak-anak yang kembali dari rumah sakit setelah perawatan asma bronkial akut, penyembuhan akan terganggu karena orang tua yang merokok (Abulhosn, Morray, Llewellyn, \& Redding, 1997).

Tahun 2007, 40,5\% penduduk semua umur (91 juta) terpajan asap rokok di dalam rumah. Sementara tahun 2010, prevalensi perokok pasif dialami oleh dua dari lima penduduk dengan jumalh berkisar 92 juta penduduk. Tahun 2013, jumlah ini meningkat menjadi sekitar 96 juta jiwa. Perempuan lebih tinggi (54\%) dari pada laki-laki $(24,2 \%)$ dan anak usia 0-4 tahun yang terpajan adalah $56 \%$ atau setara dengan 12 juta anak terpajan asap rokok (TCSC-IAKMI, 2014).

Hasil pencapaian tahun 2011, yang memberikan kontribusi terendah dan masih menjadi masalah kesehatan pada umumnya adalah tidak merokok di dalam rumah yang baru mencapai $46,67 \%$. Hasil Riskesdas 2010 menunjukkan bahwa prevalensi perokok di DIY sebesar 31,6\%, dan sebanyak 66,1\% masih merokok di dalam rumah. Persentase rumah tangga bebas asap rokok di DIY tahun 2012 baru mencapai 44,6\% (Depkes RI, 2010). Dari hasil tersebut, tidak mengherankan jika persentase perokok pasif cukup tinggi karena perokok biasa merokok di dalam rumah. Sedangkan jika dilihat dari statusnya, perokok rumah tangga didominasi suami / kepala rumah tangga (Dinkes DIY, 2013). Perokok aktif merupakan bagian dari masyarakat, saat merokok juga berinteraksi dengan nonperokok baik di keluarga maupun di komunitas, sehingga dapat diperkirakan bahwa jumlah perokok pasif atau orang yang terpapar asap rokok jumlahnya lebih banyak dari jumlah perokok aktif (Nurwidayanti \& Wahyuni, 2013).
Berdasarkan hasil survey pendahuluan, terdapat $56,76 \%$ anggota keluarga yang merokok di RT 06 Dusun Ponegaran, Desa Jambidan, Banguntapan, Bantul. Sedangkan sebagain besar, para perokok merokok didalam rumah. Hal ini akan berdampak pada anak-anak sebagai perokok pasif. Oleh karena itu perlu diberikan edukasi tentang dampak paparan asap rokok orang lain pada perokok pasif, agar mereka dapat terhindar dari paparan asap rokok.

\section{TARGET DAN LUARAN}

Sasaran kegiatan ini adalah seluruh anggota keluarga. Peran keluarga sangat dibutuhkan untuk mendukung perilaku hidup sehat tanpa asap rokok di lingkungan rumah tangga. Tujuan kegiatan penyuluhan ini adalah :

a.Meningkatkan pengetahuan warga tentang dampak paparan asap rokok orang lain pada perokok pasif

b. Meningkatkan pengetahuan warga tentang dampak ekonomi akibat konsumsi rokok

c.Meningkatkan pengetahuan warga tentang peran keluarga dalam pengendalian perilaku merokok

\section{METODE PELAKSANAAN}

Penyuluhan edukasi rumah tangga bebas asap rokok dilakukan di RT 06 Dusun Ponegaran, Desa Jambidan, Kecamatan Banguntapan, Bantul, Yogyakarta pada bulan April - Juli 2018.

Pelaksanaan intervensi ini dilakukan dengan metode penyuluhan dengan tema "Rumah Tangga Bebas Asap Rokok" menggunakan media leaflet yang dilakukan dengan mengujungi rumah warga satu per satu (door to door).

Materi penyuluhan yang diberikan antara lain adalah Dampak Paparan Asap Rokok Orang Lain Pada Perokok Pasif, Dampak Ekonomi Akibat Konsumsi Rokok dan Peran Keluarga Dalam Pengendalian Perilaku Merokok.

\section{IV.HASIL DAN PEMBAHASAN}

Hasil dari program pengabdian kepada masyarakat bertama "Penyuluhan Rumah Sehat Bebas Asap Rokok" adalah sebagai berikut :

1) Dampak Paparan Asap Rokok Orang Lain Pada Perokok Pasif

Kegiatan penyuluhan ini dilakukan di rumah warga dengan materi dampak dan bahaya merokok. Penyampaian materi ini penting dilakukan agar masyarakat dapat memahami informasi mengenai bahaya merokok dan paparan asap rokok.

Untuk mengetahui tingkat pengetahuan masyarakat tentang rumah bebas asap rokok. Setelah penyuluhan dilakukan penilaian tingkat pengetahuan warga melalui pengisisan instrumen instrumen tersebut 
berisi 10 pertanyaan seputar materi dan harus dijawab jujur oleh warga.

Ada 4 pernyataan yang diberikan kepada warga berkaitan dengan dampak paparan asap rokok pada perokok pasif yaitu :

a.Salah satu dampak paparan asap rokok pada perokok pasif adalah infeksi telinga bagian tengah

b. Paparan asap rokok tidak mengakibatkan gangguan kecerdasan pada anak

c.Perokok pasif tidak berisiko terkena penyakit jantung

d. Tidak ada perbedaan yang nyata antara kondisi paru-paru pada perokok aktif dan pasif

Materi mengenai dampak paparan asap rokok pada perokok pasif ini dimaksudkan untuk mengetahui beberapa informasi tentang akibat yang akan dirasakan oleh perokok aktif maupun pasif. Hasil dan pembahasan terhadap data tersebut dapat dilihat pada gambar 1 sebagai berikut :

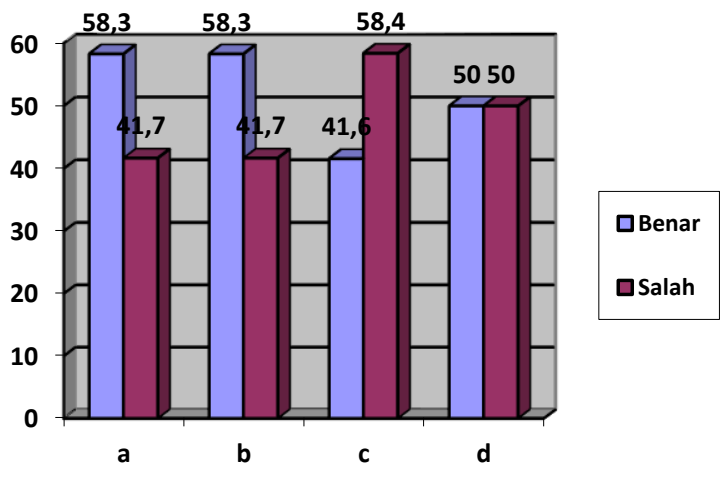

Gambar 1. Tingkat pengetahuan responden tentang dampak paparan asap rokok orang lain pada perokok pasif

Berdasarkan grafik diatas dapat dilihat bahwa Salah satu dampak paparan asap rokok pada perokok pasif adalah infeksi telinga bagian tengah, hasil persentase warga yang menjawab dengan jawaban benar sebesar 58,3\%. Dari hasil tersebut memang sebagian warga menjawab dengan benar pertanyaan yang ada di kuisioner namun tidak jauh beda dengan jawaban warga yang menjawab salah yaitu sebesar 41,7\%. Hasil tersebut menandakan bahwa masih perlunya penyuluhan tentang dampak akibat paparan asap rokok.

Resiko gangguan kesehatan yang mengancam perokok pasif dan aktif sama-sama besar. Merokok, selain merusak kesehatan orang lain juga dapat merugikan orang-orang yang berada disekitarnya. Menurut Kemenkes RI berikut adalah beberapa resiko kesehatan perokok pasif yang perlu diketahui, yaitu Mengurangi kadar vitamin dan antioksidan dalam darah, Gangguan kehamilan, Meningkatkan resiko penyakit gangguan pernapasan, Penyempitan pembuluh darah, Infeksi telinga bagian tengah, Meningkatkan resiko penyakit meningokokus, Meningkatkan resiko kanker, dan Meningkatkan resiko penyakit jantung dan stroke.

Selain itu pernyataan paparan asap rokok tidak mengakibatkan gangguan kecerdasan pada anak, pada grafik dapat dilihat bahwa hasil persentase jawaban benar sebesar 58,3\% dan jawaban salah sebesar $41,7 \%$. Dalam hal ini juga dapat dilihat bahwa persentase warga yang menjawab benar dan warga yang menjawab salah tidak jauh beda sehingga masih perlunya informasi mengenai bahaya paparan asap rokok untuk warga sekitar.

Menurut Peraturan Menteri Kesehatan Republik Indonesia Nomor 28 Tahun 2013 Tentang Pencantuman Peringatan Kesehatan dan Informasi Kesehatan pada Kemasan Produk Tembakau. Akibat dari asap rokok ini kepada anak-anak atau bayi antara lain yaitu Mengalami gangguan dan penyakit pernafasan, Terganggunya perkembangan kecerdasan anak, baik motorik maupun Kognitif, Terjangkitnya penyakit telinga, Bisa meningkatkan resiko penyakit leukimia sebanyak dua kali lipat, Meningkatkan resiko kanker otak hingga 22 persen, Bayi akan lebih mudah lelah karena oksigen yang tidak terserap,Sempurna, serta Sindrom kematian secara mendadak.

Pada pernyataan Perokok pasif tidak beresiko terkena penyakit jantung dapat dilihat grafik diatas dapat dilihat hasil persentase pada jawaban benar sebesar $41,6 \%$ lebih sedikit daripada warga yang menjawab dengan jawaban salah sebesar 58,4\%. Hal ini menandakan bahwa perlunya penyuluhan tentang dampak paparan asap rokok terutama pada perokok pasif.

Perokok pasif adalah seseorang yang menghirup asap rokok dari orang yang merokok maupun yang langsung berasal dari sisa pembakaran rokok. Perokok pasif menghirup berbagai senyawa kimia diantaranya: Amonia, Butan: Karbon monoksida, Kromium, Sianida, Formaldehid, Timbal, serta Polonium.

Partikel partikel berbahaya tersebut dapat bertahan di dalam udara selama beberapa jam atau lebih lama. Selain itu, bukan hanya asap saja yang menjadi fokus bahaya, tetapi juga residu yang menetap pada rambut serta pakaian, karpet, ataupun sofa (disebut juga perokok ketiga), juga memiliki risiko terutama pada anak-anak. Perokok pasif dapat berbahaya dan berkontribusi menjadi masalah penyakit yang serius termasuk:

a) Penyakit paru Paparan terhadap asap rokok dapat membahayakan kondisi paru-paru terutama bagi mereka yang memiliki asma atau PPOK (penyakit paru obstruktif kronik). b) Penyakit jantung Perokok pasif memiliki risiko terhadap penyakit jantung dan serangan jantung karena terjadi kerusakan pada pembuluh darah yang disebabkan oleh asap rokok. c) 
Kanker Salah satu faktor risiko kanker paru adalah perokok pasif. Selain itu, benzena yang terkandung dalam asap rokok juga dapat meningkatkan risiko terjadinya leukemia (Perdana, dkk,2014).

Sedangkan pada pernyataan Tidak ada perbedaan yang nyata antara kondisi paru-paru pada perokok aktif dan pasif dapat dilihat pada grafik bahwa hasil persentase jawaban pada kuisioner sama-sama sebesar $50 \%$ baik jawaban benar maupun salah yang berarti juga masih perlu adanya informasi tentang kondisi paru-paru yang dialami perokok pasif dan aktif.

Suatu fenomena yang jelas sekali bahwa organ pertama yang terkontaminasi oleh asap rokok dalam tubuh seseorang adalah saluran pernafasan dan paru paru. Asap rokok dengan senyawa aktif senyawa tar dan nikotin, akan mengalami reaksi yang bermula dari masuknya asap rokok dalam alveolus paru paru dan memberikan pengaruh negatif pada gelembung paru paru (Masashi et al., 2001).

Pengamatan terhadap kadar nikotin yang terdapat dalam rokok, yang beredar di Amerika di bawah pengawasan Federal Trade Commision(FTC), diperoleh bahwa pada seorang perokok sedang terdapat 48,6 mL nikotin dalam sekali isap dan 44,1 $\mathrm{mL}$ pada perokok ringan (perokok pasif). Suatu jumlah yang cukup besar dari senyawa nikotin yang dapat masuk kedalam tubuh seseorang. Sutau penelitian epidemiologi menunjukkan bahwa perokok pasif dapat menyebabkan resiko meningkatnya risiko terkena kanker paru paru pada perokok pasif tersebut.

2) Dampak Ekonomi Akibat Konsumsi Rokok Ekonomi masyarakat juga menjadi salah satu dampak akibat konsumsi rokok. Oleh karena itu materi pada kegiatan penyuluhan tentang rumah bebas asap rokok juga disampaikan mengenai dampak ekonomi akibat mengkonsumsi rokok.

Ada 3 pernyataan yang diberikan kepada warga berkaitan dengan dampak ekonomi akibat konsumsi rokok yaitu :

a.Pengeluaran masyarakat indonesia untuk belanja rokok lebih besar dibanding pengeluaran untuk bahan pokok

b. Merokok dapt menambah biaya beban kesehatan

c.Mengurangi belanja rokok selama 10 tahun dapat untuk biaya kuliah anak

Materi mengenai dampak ekonomi akibat konsumsi rokok ini diberikan agar warga dapat mengetahui dampak yang akan timbul apabila tetap mengkonsumsi rokok dan akan menghambat biaya beban kesehatan dan biaya pendidikan anak. Hasil dan pembahasan terhadap data tersebut dapat dilihat pada gambar 2 sebagai berikut :

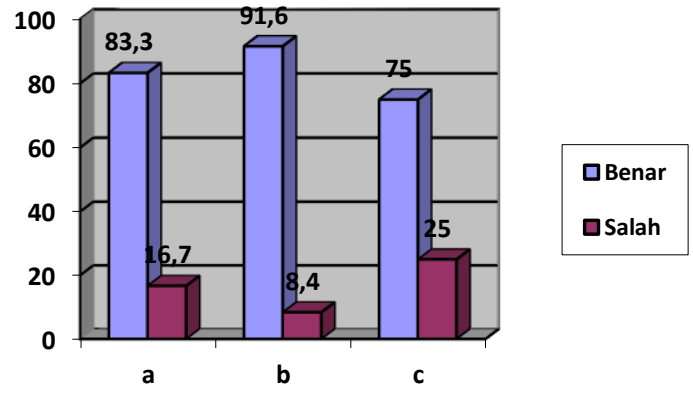

Gambar 2. Grafik tingkat pengetahuan responden tentang dampak ekonomi akibat konsumsi rokok

Berdasarkan grafik diatas Pengeluaran masyarakat Indonesia untuk belanja rokok lebih besar di banding pengeluaran untuk bahan pokok. Hasil persentase pada yaitu jawaban benar 83,3 \% lebih besar daripada persentase jawaban salah sebesar $16,7 \%$ yang berarti warga tahu bahwa pengeluaran pembelian rokok lebih besar daripada pengeluaran untuk bahan pokok.

Hal ini sangat berdampak pada kondisi ekonomi masyarakat. Di Indonesia, pengeluaran untuk rokok menjadi pengeluaran nomor dua setelah padi-padian yang besarnya rata-rata 10,4\% atau 4 kali lipat lebih besar daripada pengeluaran untuk membeli daging dan susu. Sehingga perlu adanya intervensi terkait dampak merokok selain membahayakan kesehatan juga menjadi permasalahan ekonomi keluarga.

Pada pernyataan Merokok dapat menambah biaya beban kesehatan dapat dilihat pada grafik Hasil persentase jawaban warga yang menjawab benar 91,6 \% dan yang menjawab salah sebesar 8,4 \%, yang berarti warga sudah tau akan penambahan biaya kesehatan yang terjadi bila terkena dampak dari merokok tersebut. Walaupu begitu masih terdapat warga yang menjawab salah sehingga masih perlu diberi informasi dan diberi peringatan melalui penyuluhan tentang bahaya merokok.

Resiko merokok sendiri banyak memiliki dampak bagi kesehatan, diantaranya terserang berbagai penyakit tidak menular (PTM) sehingga apabila perokok sudah terkena salah satu dari penyakit tidak menular tersebut akan menyebabkan penambahan biaya beban kesehatan.

Pernyataan mengurangi belanja rokok selama 10 tahun dapat untuk biaya kuliah anak, juga dapat dilihat pada grafik diatas menunjukan bahwa Hasil persentase warga yang menjawab benar $75 \%$ dan yang menjawab dengan jawaban salah sebesar $25 \%$, yang berarti masih terdapat warga yang belum mengetahui dampak belanja merokok terhadap biaya pendidikan maupun kesehatan.

Pengeluaran rokok sendiri adalah 3 kali lebih tinggi dari biaya pendidikan $(3,2 \%)$. Hal ini menunjukan bahwa dengan mengurangi belanja rokok selama 10 
tahun dapat untuk membiayai pendidikan anak lebih banyak dibandingkan dibelanjakan untuk rokok.

3) Peran Keluarga Dalam Pengendalian Perilaku Merokok

Peran keluarga dalam pengendalian perilaku merokok ini juga masuk dalam materi penyuluhan rumah bebas asap rokok. Ada 3 pernyataan yang meliputi materi peran keluarga dalam pengendalian perilaku merokok yaitu :

a.Tidak menyediakan asbak di dalam rumah merupakan salah satu peran keluarga untuk mewujudkan rumah tanpa asap rokok

b. Tamu boleh merokok di rumah yang dikunjungi

c.Salah satu peran keluarga dan kader kesehatan adalah menggalang rumah tanpa asap rokok

Materi ini disampaikan agar warga dapat mengetahui hal apa saja yang harus dilakukan untuk pengendalian merokok agar tercipta rumah bebas asap rokok. Hasil dan pembahasan data tersebut dapat dilihat pada grafik dibawah ini :
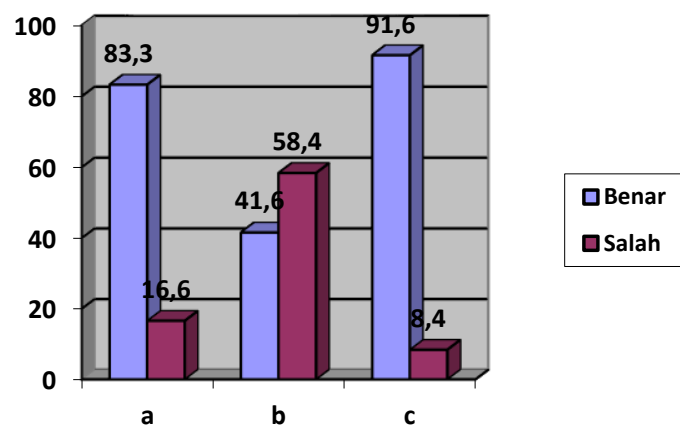

$\square$ Salah

Gambar 3. Grafik tigkat pengetahuan responden tentang peran keluarga dalam pengendalian perilaku merokok

Berdasarkan grafik diatas Pernyataan Tidak menyediakan asbak didalam rumah merupakan salah satu peran keluarga untuk mewujudkan rumah tanpa asap rokok, Hasil persentase menunjukan bahwa jawaban warga yang benar benar sebesar 83,3\% lebih besar dari pada warga yang menjawab dengan jawaban salah sebesar 16,6 \%. Walaupun banyak warga yang menjawab benar, namun masih terdapat warga yang menjawab dengan salah sehingga masih perlu diingatkan dengan cara penyuluhan kepada warga tentang pengendalian perilaku merokok.

Menurut kementerian kesehatan tahun 2017, peran keluarga dan kader untuk menciptakan rumah tanpa asap rokok salah satunya adalah tidak memberi dukungan kepada orang yang merokok dalam bentuk apapun antara lain dengan tidak memberikan uang untuk membeli rook, tidak memberikan kesempatan kepada siapapun untuk merokok didalam rumah dan tidak menyediakan asbak.

Pernyataan mengenai Tamu boleh merokok dirumah yang di kunjungi juga dapat dilihat pada grafik diatas dan diperoleh hasil persentase yang menjawab dengan jawaban benar 41,6 \% dan jawaban salah sebesar 58,4 \% yang berarti masih banyak warga yang tidak mengetahui bahwa tidak boleh merokok dirumah. Hal ini sesuai dengan pernyataan kementerian kesehatan tahun 2017 dalam buku hidup sehat tanpa rokok yaitu untuk menciptakan rumah tanpa asap rokok tidak boleh memberikan kesempatan kepada siapapun untuk merokok didalam rumah. Sehingga masih diperlukan penyuluhan tentang pengendalian merokok.

Sedangkan pada pernyataan Salah satu peran keluarga dan kader kesehatan adalah menggalang rumah tanpa asap rokok terlihat pada grafik menunjukan bahwa persentase jawaban warga yang menjawab benar sebesar 91,6 \% dan jawaban salah sebesar 8,4\% yang berarti menunjukkan bahwa warga sebagian besar sudah mengetahui peran untuk menciptakan rumah tanpa asap rokok.

Hal ini didukung dengan pernyataan kementerian kesehatan bahwa Peran keluarga dan kader untuk menciptakan rumah tanpa asap rokok diantaranya adalah Memberikan penyuluhan tentang pentingnya perilaku tidak merokok kepada seluruh anggota keluarga, menggalang kesepakatan keluarga untuk menciptakan rumah tangga tanpa asap rokok, Menegur anggota rumah tangga yang merokok di dalam rumah, Tidak memberi dukungan kepada orang yang merokok dalam bentuk apapun, antara lain dengan tidak memberikan uang untuk membeli rokok, tidak memberikan kesempatan kepada siapapun untuk merokok di dalam rumah, tidak menyediakan asbak, tidak menyuruh anaknya membelikan rokok untuknya, Orangtua bisa menjadi panutan dalam perilaku tidak merokok, Melarang anak tidak merokok bukan karena alasan ekonomi, tetapi justru karena alasan kesehatan.

Kendala dalam pelaksanaan penyuluhan ini adalah intervensi tidak dapat dilakukan kepada seluruh warga di RT 06 Dusun Ponegaran dikarenakan saat kunjungan warga sedang tidak berada di rumah dan membutuhkan waktu yang cukup lama saat melakukan kunjungan ke rumah warga satu per satu. Namun, kerja sama yang sangat baik dari masingmasing ketua RT dan tokoh masyarakat lainnya sangat membantu pelaksanaan penyuluhan ini. Warga yang didatangi selalu sudah menyiapkan diri dengan kedatangan pelaksana kegiatan.

\section{KESIMPULAN}

Berdasarkan hasil pelaksanaan kegiatan penyuluhan yang diadakan di RT 06 Dusun Ponegaran, Desa Jambidan, Kecamatan Banguntapan, Bantul. Masih perlu adamya penyuluhan atau intervensi tentang dampak akibat merokok, dampak paparan asap pada perokok pasif maupun aktif, dan pengendalian terhadap perilaku merokok. Mengingat bahaya rokok 
dalam kesehatan bagi masyarakat maka terdapat rekomendasi atau saran untuk selanjutnya diharapkan agar kader atau tenaga kesehatan dapat memberikan penyuluhan dengan frekuensi yang lebih sering dan ditambahkan materi mengenai rumah bebas asap rokok.

\section{UCAPAN TERIMA KASIH}

Terima kasih kami ucapkan kepada Program Studi Ilmu Keseatan Masyarakat, Fakultas Kesehatan Masyarakat, Universitas Ahmad Dahlan, Yogyakarta yang telah mendanai program PPM 2018.

\section{DAFTAR PUSTAKA}

[1] Abulhosn, R., Morray, B., Llewellyn, C., \& Redding, G., 1997, Passive Smoke Exposure Impairs Recovery After Hospitalization For Acute Asthma, Archives of Pediatrics \& Adolescent Medicine, Vol. 151 No. 2 , Hal. 135-9.

[2] Bustan, M. N, 2000, Epidemiologi Penyakit Tidak Menular, Jakarta: PT. Rineka Cipta.

[3] Dinkes DIY, 2013, Profil Kesehatan DIY tahun 2012, Dinkes DIY, Yogyakarta

[4] Departemen Kesehatan RI., 2010, Riset Kesehatan Dasar tahun 2010, Jakarta: Kementerian Kesehatan Republik Indonesia.

[5] Emilda, R., 2014, Paparan Asap Rokok Sebagai Faktor Risiko Asma Pada Anak Dengan Rinitis Alergika, Yogyakarta: Program Pascasarjana UGM.

[6] Masashi,K., Hiromasa,I., Koichiro,M., Hiroshi,K., Satoru,F., Hisamichi,A.,\&Nobuyuki,H, 2001, PAF mediates cigarette smoke-induced gobletcell metaplasia in guinea pig airways. AJP Lung Cell Mol Physiology; 280:L436-L441

[7] Perdana A., Agung Eko, 2014, Kampanye Pencegahan Perokok Pasif Pada Anak-Anak, Jurnal Tingkat Sarjana Bidang Senirupa Dan Desain, Bandung : Fakultas Seni Rupa Dan Desain (FSRD) ITB

[8] Mukono, H., 2005, Toksikologi Lingkungan, Surabaya: Airlangga University Press.

[9] Nurwidayanti, L., \& Wahyuni, C. U., 2013, Analisis Pengaruh Paparan Asap Rokok di Rumah Pada Wanita Terhadap Kejadian Hipertensi, Jurnal Berkala Epidemiologi, Vol. 1, No. 2 , 244-253.

[10] Pudjiastuti,dkk., 1998, Kualitas Udara dalam Ruang, Jakarta: Dirjen PT Departemen Pendidikan dan Kebudayaan.

[11] Rai, I., \& Artana, I, 2009, Merokok dan Ketergantungan Nikotin pada Penduduk tenganan Pengrisingan, Karangasem, Bali, Jurnal Respirologi Indonesia, Vol. 29 No. 4.

[12] Tobacco Control and Support Center-IAKMI, 2014, Bunga Rampai - Fakta Tembakau dan Permasalahannya, Edisi V, Jakarta : Tobacco Control and Support Center-IAKMI 